\title{
Pengaruh dana alokasi umum DAU dana alokasi khusus DAK dan pendapatan asli daerah PAD terhadap belanja modal
}

\author{
Hairiyah $^{1}$, Lewi Malisan ${ }^{2}$, Zaki Fakhroni ${ }^{3}$ \\ Fakultas Ekonomi dan Bisnis Universitas Mulawarman, Samarinda. \\ ${ }^{1}$ Email: hairiyah@mhs.feb.unmul.ac.id \\ ${ }^{2}$ Email: lewi.malisan@feb.unmul.ac.id \\ ${ }^{3}$ Email: zaki.fakhroni@feb.unmul.ac.id
}

\begin{abstract}
Abstrak
Penelitian ini bertujuan untuk mengetahui ada atau tidaknya pengaruh Dana Alokasi Umum, Dana Alokasi Khusus dan Pendapatan Asli Daerah terhadap Belanja Modal. Penelitian ini menggunakan data skunder yang diambil langsung dari laporan realisasi Anggaran dan Pendapatan Dan Belanja Daerah (APBD) Kabupaten/Kota Se-Kalimantan Timur yaitu Dana Alokasi Umum, Dana Alokasi Khusus, Pendapatan Asli Daerah dan Belanja Modal periode tahun 2010-2015. Analisis data menggunakan bantuan uji asumsi klasik yang dibantu oleh software SPSS 21 untuk mengetahui pengaruh variabel independen terhadap variabel dependen.
\end{abstract}

Kata Kunci: Dana alokasi umum; dana alokasi khusus; pendapatan asli daerah

\section{Influence of general allocation fund of DAU special allocation fund of DAK and revenue of indigenous PAD to capital expenditure}

\begin{abstract}
This study aims to determine whether or not the effect of General Allocation Funds, Special Allocation Funds and Local Original Income to Capital Expenditures. This study uses the secondary data taken directly from the realization report of Regional Budget and Income (APBD) of Regency / City of East Kalimantan that is General Allocation Fund, Special Allocation Fund, Local Original Income and Capital Expenditure period 2010-2015. Data analysis using classical assumption assistance assisted by SPSS 21 software to know the effect of independent variable to dependent variable.
\end{abstract}

Keywords: General allocation fund; special allocation fund; local own revenue 


\section{PENDAHULUAN}

Pembiayaan penyelenggaraan pemerintah berdasarkan asas desentralisasi dilakukan atas beban Anggaran Pendapatan dan Belanja Daerah (APBD). Dalam rangka penyelenggaraan pemerintah dan pelayanan kepada masyarakat yang berdasarkan asa desentralisasi, daerah diberikan kewenangan untuk memungut pajak/retrebusi dan mengelola Sumber Daya Alam (SDA). Sumber dana bagi daerah terdiri dari Pendapatan Asli Daerah (PAD), Dana Perimbangan (Dana Bagi Hasil, Dana Alokasi Umum dan Dana Alokasi Khusus) dan Pinjaman Daerah, Dekosentrasi dan Tugas Pembantuan. Tiga sumber pertama akan dikelola oleh Pemerintah Daerah melalui APBD, sedangkan yang lain dikelola oleh pemerintah Pusat melalui kerjasama dengan pemerintah daerah (Halim:2007).

Tujuan utama pemberian dana perimbangan kepada pemerintah daerah adalah untuk mengurangi kesenjangan fiskal antara pemerintah pusat dan pemeritah daerah serta menjamin tercapai standar pelayanan publik. Dana perimbangan oleh pemerintah pusat seharusnya bukan menjadikan pemerintah bergantung sepenuhnya terhadap pemerintah pusat dalam melaksanakan pemerintahan. Namun pemerintah daerah dituntut agar tetap memaksimalkan potensi daerah untuk mengahasilkan sendiri sumber pendanaan melalui peningkatan Pendapatan Asli Daerah (PAD).

Pendapatan Asli Daerah (PAD) menjadi tulang punggung dalam pembiayaan daerah. Kemampuan suatu daerah menggali pendapatan asli daerah akan mempengaruhi perkembangan dan pembangunan daerah tersebut. Dalam konstribusinya terhadap APBD dimana semakin besar konstribusi PAD terhadap APBD, maka akan semakin kecil pada ketergantungan terhadap bantuan pemerintah pusat. Untuk dapat mengetahui terjadinya peningkatan kemandirian daerah, pendapatan asli daerah bisa dijadikan sebagai tolak ukurnya karena pendapatan asli daerah ini sendiri merupakan komponen penting yang mencerminkan bagaimana sebuah daerah mendanai sendiri kegiatannya melalui komponen pendapatan yang murni dihasilkan melalui daerah tersebut (Darwanis ,2014) Permasalahan Dana Alokasi Umum dan Dana Alokasi Khusus terletak pada perbedaan cara pandang antara pemerintah pusat dan daerah. Bagi pusat DAU dan DAK dijadikan sebagai instrument horizontal imbalance. Bagi daerah, DAU dan DAK dimaksudkan untuk mendukung kecukupan pembiayaan daerah. Permasalahan timbul ketika daerah meminta DAU dan DAK yang besar atau sesuai dengan kebutuhan pembiyaan daerahnya. Disisi lain, alokasi DAU dan DAK berdasarkan kebutuhan daerah dilakukan karena dasar perhitungan fiscal needs tidak memadai (terbatasnya data, belum adanya standar pelayanan minimum masingmasing daerah dan sistem penganggaran yang belum berdasar pada standar analisis belanja). Ditambah total pengeluaran anggaran khususnya APBD belum mencerminkan kebutuhan sesungguhnya dan cenderung penggunaan DAU dan DAK menjadi tidak efisien. Berdasarkan data diketahui nilai Dana Alokasi Umum pada tahun 2010 sebesar 1.481.186.065 (dalam ribu rupiah) lalu meningkat tahun 2011 sebesar 3.480.399.881 (dalam ribu rupiah) kemudian meningkat pada tahun 2012 sebesar 4.379.253.951 (dalam ribu rupiah) kemudian meningkat lagi pada tahun 2013 sebesar 5.030.195.383 (dalam ribu rupiah) lalu mengalami penurunan lagi pada tahun 2014 sebesar 3.515.834.410 dan menurun lagi pada tahun 2015 yaitu sebesar 3.066.049.732 Pada Dana Alokasi Khusus dapat di lihat pada tahun 2010 sebesar 236.895.491 lalu mengalami peningkatan pada tahun 2011 sebesar 281.674.200 pada tahun 2012 meningkat sebesar 292.668.870 pada tahun 2013 mengalami peningkatan sebesar 447.409.420 dan pada tahun 2014 mengalami penurunan lagi sebesar 230.300.140 dan penurunan lagi sebesar 119.863.750 Pada tabel di atas juga dapat dilihat Pendapatan Asli Daerah yaitu pada tahun 2010 sebesar 1.483.462.728 pada tahun 2011 penurunan sebesar 1.234.446.302 pada tahun 2012 mengalami kanaikan yaitu sebesar 1.440.574.965 pada tahun 2013 mengalami kenaikan lagi sebesar 1.597.644.034 dan pada tahun 2014 mengalami kenaikan sebesar 1.716.658.452 dan mengalami kenaikan lgi sebesar 1.998.945.182 pada tahun 2015. Pada Belanja Modal pada tahun 2010 sebesar 9.250.511.245 pada tahun 2011 turun sebesar 9.036.911.733 pada tahun 2012 kembali mengalami kenaikan sebesar 10.805.091.959 lalu pada tahun 2013 naik sebesar 15.982.537.104 dan pada tahun 2014 mengalami penurunan sebesar 12.790.849.659 serta pada tahun 2015 mengalamin penurunan lagi sebesar 11.933.015.143. Dapat dilihat sejak tahun 2010-2015 DAU,DAK, PAD dan Belanja Modal kab/kota Kalimantan Timur mengalami fluktuasi setiap tahunnya. Dapat dilihat juga bahwa belanja modal lebih besar dari pada DAU, DAK, PAD sehingga dapat di artikan bahwa belanja modal Kalimantan Timur dibiayai oleh DAU, DAK, PAD tetapi juga oleh APBN, karena APBN tidak hanya mentransfer 
dana berupa DAK,DAU tetapi juga Dana Bagi Hasil Alokasi dana untuk Belanja Modal cukup besar dan dapat ketahui juga tujuan pemekaran adalah untuk mensejahterakan masyarakat dan agar terjadinya percepatan pembangunan namun kenyataan setelah terjadinya pemekaran yaitu masih adanya jalanan di Kalimantan Timur yang rusak, contoh nya pada jalanan Samarinda menuju Sangattan, Samarinda menuju Bontang,Samarinda menuju Balik papan dan jalanan daerah-daerah menuju pedalaman Kalimantan Timur seperti Kabupaten Kutai Barat yang masih penuh dengan lobang dan tanah liat serta di daerah Kutai Barat khususnya di Kecamatan Muara Pahu masih minimnya terdapat listrik disana hanya malam hari mendapatkan listrik. Dan juga jalanan di dalam Kota Samarinda masih banyak yang rusak serta di Kota Samarinda masih sering terjadi banjir.

\section{METODE}

Data yang digunakan dalam penelitian ini adalah data sekunder bersumber dari dokumen ringkasan Laporan Realisasi Anggaran dan Pendapatan Belanda Daerah (APBD) Kebupaten/Kota di Provinsi Kalimantan Timur yang diperoleh dari BPSKalimantan Timur. Dari ringkasan Laporan Realisasi APBD tersebut akan diperoleh data mengenai jumlah Dana Alokasi Umum, Dana Alokasi Khusus, Pendapatan Asli Daerah, dan Belanja Modal. Variabel independen dalam penelitian ini adalah Dana Alokasi Umum, Dana Alokasi Khusus, dan Pendapatan Asli Daerah, sedangkan variabel dependen dalam penelitian ini adalah Belanja Modal Analisis data dalam penelitian ini berupa uji statistic deskriptif, uji asumsi klasik dengan menggunakan bantuan program software SPSS (Statistical Program For Social Science) versi21.

Statistik deskriptif dalam penelitian ini digunakan untuk melihat distribusi data dari variabelvariabel yang digunakan dalam Uji heteoskedastisitas bertujuan menguji apakah dalam model regresi terjadi ketidaksamaan variance dari residual satu pengamatan ke pengamatan yang lain. Jika variance dari residual satu pengamatan ke pengamatan yang lain tetap, maka disebut Heteoskedastisitas dan jika berbeda disebut Heteoskedastisitas (Ghozali, 2013: 139). Uji autokorelasi bertujuan menguji apakah dalam model regresi linier ada korelasi antara kesalahan pengganggu pada periode $\mathrm{t}$ dengan kesalahan pengganggu pada periode t-1 (sebelumnya). Jika terjadi korelasi, maka dinamakan ada problem autokorelasi. Autokorelasi muncul karena observasi yang berurutan sepanjang waktu berkaitan satu sama lainnya (Ghozali 2013: 110). Koefisien Determinasi (R2) pada intinya mengukur seberapa jauh kemampuan model dalam menerangkan variasi variabel dependen. Nilai koefisien determinasi adalah antara nol dan satu. Nilai R2 yang kecil berarti kemampuan variabel-variabel independen dalam menjelaskan variabel-variabel independen memberikan hampir semua informasi yang dibutuhkan untuk memprediksivariiasi variabel dependen (Ghozali, 2013: 97).

Uji statistik F pada dasarnya menunjukkan apakah semua variabel independen atau bebas yang dimasukkan dalam model mempunyai pengaruh secara bersama-sama terhadap variabel dependen/terkait. Hipotesis nol (H0) yang hendak diuji adalah apakah semua parameter dalam model sama dengan nol. Uji statistik $\mathrm{t}$ pada dasarnya menunjukan seberapa jauh pengaruh satu variabel penjelas/independen secara individual dalam menerangkan variasi variabel dependen (Ghozali 2013: 98). Pengujian dilakukan dengan menggunakan significance level 0,05.

\section{HASIL DAN PEMBAHASAN}

\section{Sebelum Pemekaran Kalimantan Utara}

\section{a. Hubungan Dana Alokasi Umum dengan Belanja Modal}

Berdasarkan persamaan regresi pada tabel 4.17 di atas diperoleh koefisien regresi Dana Alokasi Umum (DAU) sebesar -0,381. Hal tersebut menunjukkan bahwa setiap peningkatan nilai Dana Alokasi Umum sebesar satu satuan maka akan menurunkan nilai Belanja Modal sebesar -0,381.

Menunjukkan t hitung untuk Dana Alokasi Umum -2,864 dengan angka signifikan sebesar $0,007<0,05$. Maka dapat disimpulkan bahwa secara parsial Dana Alokasi Umum berpengaruh negatif dan signifikan terhadap belanja modal pada Kabupaten/Kota provinsi Kalimantan Timur sebelum terjadinya pemekaran Kalimantan Utara. Hasil ini menjelaskan bahwa Kabupaten/Kota yang mendapatkan DAU yang besar akan cenderung memiliki belanja Modal yang rendah. Hal ini di sebabkan karena DAU digunakan untuk membiayai belanja yang lain seperti belanja pegawai, belanja 
barang dan jasa serta belanja lainnya. Penelitian sejalan dengan penelitian sebelumnya yaitu yang di lakukan oleh Yovina (2011) dan Wandira (2013) yang memberikan hasil DAU berpengaruh signifikan dengan arah negatif terhadap belanja modal. Hal ini disebabkan DAU lebih banyak digunakan untuk membiayai belanja yang lain selain belanja modal.

\section{b. Hubungan Dana Alokasi Khusus dengan Belanja Modal}

Berdasarkan persamaan regresi pada tabel 4.17 di atas diperoleh koefisien regresi Dana Alokasi Khusus (DAK) sebesar 1,032. Hal tersebut menunjukkan bahwa setiap peningkatan nilai Dana Alokasi Khusus sebesar satu satuan maka akan menaikkan nilai Belanja Modal sebesar 1,032. Pada tabel tersebut juga menunjukkan $\mathrm{t}$ hitung untuk Dana Alokasi Khusus 2,967 dengan angka signifikan sebesar 0,005<0,05. Maka dapat disimpulkan bahwa secara parsial Dana Alokasi Khusus berpengaruh positif dan signifikan terhadap belanja modal pada Kabupaten/Kota provinsi Kalimantan Timur sebelum terjadinya pemekaran Kalimantan Utara. Hasil penelitian ini tidak sesuai dengan penelitian sebelumnya yang dilakukan oleh Nugroho (2014) yang menemukan bahwa DAK tidak berpengaruh signifikan terhadap Belanja Modal. Hasil penelitian ini menjelaskan bahwa Kabupaten/Kota yang mendapatkan DAK yang besar akan cenderung memiliki belanja modal yang besar pula. Hasil memberikan adanya indikasi yangkuat bahwa perilaku belanja modal akan sangat dipengaruhi dari sumber penerimaan DAK. Pendapatan daerah yang berupa dana transfer dari pusat menuntut daerah membangun dan mensejahterakan rakyatnya melalui pengelolaan kekayaan daerah yang proposional dan professional serta membangun infrastruktur yang berkelanjutan, salah satunya pengalokasian anggaran ke sektor belanja modal. Pemerintah daerah dapat menggunakan DAK untuk memberikan pelayanan kepada publik yang direalisasikan melalui belanja modal. DAK diberikan dengan tujuan untuk mebiayai kegiatan-kegiatan khusus pada daerah tertentu yang merupakan urusan daerah dan sesuai dengan prioritas nasional, khususnya membiayai kebutuhan sarana dan prasarana pelayanan dasar masyarakat yang belum mencapai standar tertentu atau mendorong percepatan pembangunan daerah.

\section{c. Hubungan Pendapatan Asli Daerah dengan Belanja Modal}

Berdasarkan persamaan regresi pada tabel 4.17 di atas diperoleh koefisien regresi Pendapatan Asli Daerah (PAD) sebesar 0,688. Hal tersebut menunjukkan bahwa setiap peningkatan nilai Pendapatan Asli Daerah sebesar satu satuan maka akan menaikkan nilai Belanja Modal sebesar 0,688. Pada tabel tersebut juga menunjukkan t hitung untuk Dana Alokasi Khusus 3,106 dengan angka signifikan sebesar $0,004<0,05$. Maka dapat disimpulkan bahwa secara parsial Pendapatan Asli Daerah berpengaruh positif dan signifikan terhadap belanja modal pada Kabupaten/Kota provinsi Kalimantan Timur sebelum terjadinya pemekaran Kalimantan Utara. Hal ini sesuai dengan teori yang dikemukakan oleh Wagner pada abad ke 19 yaitu dalam suatu perekonomian, apabila pendapatan perkapita meningkat, secara relatif pengeluaran pemerintah pun akan meningkat. Hasil penelitian ini sesuai dengan hail penelitian Rahmawati (2010) yang menemukan secara parsial PAD berpengaruh signifikan dan positif terhadap belanja langsung. Hal ini disebabkan karena PAD merupakan sumber pendapatan yang diperoleh dari daerah itu sendiri yang digunakan untuk membiayai penyelenggaraan pemerintah dan pembangunan daerah. PAD juga merupakan sumber pembelanjaan daerah, sehingga jika PAD meningkat dana yang di miliki pemerintah daerah akan lebih tinggi dan tingkat kemandirian daerah akan meningkat pula, sehingga pemerintah daerah akan berinisiatif untuk lebih meningkatkan belanja modalnya untuk melengkapi sarana prasarana pembangunan daerah guna meningkatkan pelayanan publik. Maka dapat di simpulkan jika PAD meningkat maka Belanja Modal pun akan meningkat.

\section{Sesudah Pemekaran Kalimantan Utara}

\section{a. Hubungan Dana Alokasi Umum dengan}

Belanja Modal Berdasarkan persamaan regresi pada tabel 4.19 di atas diperoleh koefisien regresi Dana Alokasi Umum (DAU) sebesar -0,195. Hal tersebut menunjukkan bahwa setiap peningkatan nilai Dana Alokasi Umum sebesar satu satuan maka akan menurunkan nilai Belanja Modal sebesar $-0,195$. 
Pada tabel tersebut juga menunjukkan t hitung untuk Dana Alokasi Umum -0,849 dengan angka signifikan sebesar 0,404>0,05. Maka dapat disimpulkan bahwa Dana Alokasi Umum berpengaruh negatif dan tidak signifikan terhadap belanja modal pada Kabupaten/Kota provinsi Kalimantan Timur sebelum terjadinya pemekaran Kalimantan Utara. Hal tidak sejalan dengan penelitian sebelum yang dilakukan oleh Sari (2009) yang menemukan secara parsial DAU berpengaruh signifikan terhadap belanja modal. Hal ini di sebabkan karena dana transfer berupa DAU yang diberikan oleh pemerintah pusat tidak semuanya digunakan untuk belanja modal. DAU banyak dialokasin untuk membiayai belanja pegawai,belanja barang dan jasa serta belanja lainnya. Hal ini juga di sebabkan oleh beberapa faktor anggaran belanja modal yang digunakan tidak juga hanya berasal dari dana transfer (DAU) tetapi dapat diambil dari anggaran lainnya seperti pendapatan asli daerah.Hal ini juga di sebabkan oleh tidak semua kabupaten/kota di Kalimantan Timur mendapatkan aliran DAU dari pemerintah pusat. Karena tujuan awal DAU adalah untuk pemerataan keuangan antar daerah yang dimkasudkan untuk mengurangi ketimpangan kemampuan keuangan antar daerah. suatu daerah yang potensi fiskalnya tinggi maka DAU yang di peroleh daerah yang bersangkutan rendah. Maka dalam hal ini dapat dikatakan Kabupaten/kota di provinsi Kalimantan Timur tidak terganggung dari DAU dari pemerintah pusat untuk membiayai Belanja Modal.

\section{b. Hubungan Dana Alokasi Khusus dengan}

Belanja Modal Berdasarkan persamaan regresi pada tabel 4.19 di atas diperoleh koefisien regresi Dana Alokasi Khusus (DAK) sebesar 1,825. Hal tersebut menunjukkan bahwa setiap peningkatan nilai Dana Alokasi Khusus sebesar satu satuan maka akan menaikkan nilai Belanja Modal sebesar 1,825 .

Pada tabel tersebut juga menunjukkan $t$ hitung untuk Dana Alokasi Khusus 3,485 dengan angka signifikan sebesar $0,002<0,05$. Maka dapat disimpulkan bahwa secara parsial Dana Alokasi Khusus berpengaruh positif dan signifikan terhadap belanja modal pada Kabupaten/Kota provinsi Kalimantan Timur sebelum terjadinya pemekaran Kalimantan Utara. Hasil penelitian ni tidak sesuai dengan penelitian sebelumnya yang dilakukan oleh Nugroho (2014) yang menemukan bahwa DAK tidak berpengaruh signifikan terhadap Belanja Modal. Hasil penelitian ini menjelaskan bahwa Kabupaten/Kota yang mendapatkan DAK yang besar akan cenderung memiliki belanja modal yang besar pula. Hasil memberikan adanya indikasi yang kuat bahwa perilaku belanja modal akan sangat dipengaruhi dari sumber penerimaan DAK. Pendapatan daerah yang berupa dana transfer dari pusat menuntut daerah membangun dan mensejahterakan rakyatnya melalui pengelolaan kekayaan daerah yang proposional dan professional serta membangun infrastruktur yang berkelanjutan, salah satunya pengalokasian anggaran ke sektor belanja modal. Pemerintah daerah dapat menggunakan DAK untuk memberikan pelayanan kepada publik yang direalisasikan melalui belanja modal. DAK diberikan dengan tujuan untuk mebiayai kegiatan-kegiatan khusus pada daerah tertentu yang merupakan urusan daerah dan sesuai dengan prioritas nasional, khususnya membiayai kebutuhan sarana dan prasarana pelayanan dasar masyarakat yang belum mencapai standar tertentu atau mendorong percepatan pembangunan daerah.

\section{c. Hubungan Pendapatan Asli Daerah dengan Belanja Modal}

Berdasarkan persamaan regresi pada tabel 4.19 di atas diperoleh koefisien regresi Pendapatan Asli Daerah (PAD) sebesar 1,307. Hal tersebut menunjukkan bahwa setiap peningkatan nilai Pendapatan Asli Daerah sebesar satu satuan maka akan menaikkan nilai Belanja Modal sebesar 1,307. Pada tabel tersebut juga menunjukkan t hitung untuk Dana Alokasi Khusus 5,442 dengan angka signifikan sebesar $0,000<0,05$. Maka dapat disimpulkan bahwa secara parsial Pendapatan Asli Daerah berpengaruh positif dan signifikan terhadap belanja modal pada Kabupaten/Kota provinsi Kalimantan Timur sebelum terjadinya pemekaran Kalimantan Utara. Hal ini sesuai dengan teori yang dikemukakan oleh Wagner pada abad ke 19 yaitu dalam suatu perekonomian, apabila pendapatan perkapita meningkat, secara relatif pengeluaran pemeintah pun akan meningkat.

Hasil penelitian ini sesuai dengan hail penelitian Rahmawati (2010) yang menemukan secara parsial PAD berpengaruh signifikan dan positif terhadap belanja langsung. Hal ini disebabkan karena PAD merupakan sumber pendapatan yang di peroleh dari daerah itu sendiri yang digunakan untuk 
membiayai penyelenggaraan pemerintah dan pembangunan daerah. PAD juga merupakan sumber pembelanjaan daerah, sehingga jika PAD meningkat dana yang di miliki pemerintah daerah akan lebih tinggi dan tingkat kemandirian daerah akan meningkat pula, sehingga pemerintah daerah akan berinisiatif untuk lebih meningkatkan belanja modalnya untuk melengkapi sarana prasarana pembangunan daerah guna meningkatkan pelayanan publik. Maka dapat di simpulkan jika PAD meningkat maka Belanja Modal pun akan meningkat. kecil dari nilai rata-rata menunjukkan bahwa distribusi data cenderung normal Pendapatan Asli Daerah (SQRT_PAD) Pendapatan Asli Daerah memiliki nilai minimum sebesar Rp 3.172 (ribuan rupiah. Nilai maksimum sebesar Rp 23.743 (ribuan rupiah). Nilai rata-rata (mean) Rp 9.174,99 (ribuan rupiah). Dan nilai standar deviation Rp 3.897,787 (ribuan rupiah). Nilai standar deviation lebih kecil dari nilai rata-rata menunjukkan bahwa distribusi data cenderung normal.

Belanja Modal (SQRT_BM) Belanja Modal memiliki nilai minimum sebesar Rp 16.710 (ribuan rupiah). Nilai maksimum sebesar Rp 45.833 (ribuan rupiah). Nilai rata-rata (mean) Rp 25.535,87 (ribuan rupiah). Dan nilai standar deviation Rp 6.448,903 (ribuan rupiah). Nilai standar deviation lebih kecil dari nilai rata-rata menunjukkan bahwa distribusi data cenderung normal

\section{SIMPULAN}

Berdasarkan hasil analisis data dan pembahasan tentang pengaruh Dana Alokasi Umum, Dana Alokasi Khusus, Pendapatan Asli Daerah terhadap Belanja Modal pada Kab/Kota Se-Kalimantan Timur sebelum dan sesudah Pemekaran Wilayah Kalimantan Utara maka dapat diambil kesimpulan yaitu sebelum terjadinya pemekaran Dana Alokasi Umum berpengaruh signifikan tetapi negatif terhadap Belanja Modal, Dana Alokasi Khusus berpengaruh signifikan dan positif terhadap Belanja Modal, Pendapatan Asli Daerah berpengaruh signifikan dan positif terhadap Belanja Modal. Sesudah pemekaran Dana Alokasi Umum berpengaruh tidak signifikan dan negatif terhadap Belanja Modal, Dana Alokasi Khusus berpengarus signifikan dan positif terhadap Belanja Modal dan Pendapatan Asli Daerah berpengaruh signifikan dan positif terhadap Belanja Modal.

\section{DAFTAR PUSTAKA}

Asriani, 2016. Analisis Kontribusi Dana Alokasi Umum (DAU) dan Pendapatan Asli Daerah (PAD) pada Anggaran Pendapatan dan Belanja Daerah (APBD) di Provinsi Kalimantan Timur

Atmadja, Arifin P. Soeria, 2009. Keuangan Publik dalam Perpektif Hukum, Edisi 1, Rajawali pers. Jakarta

Badan Pusat Statistik. 2015. Statistik Keuangan Pemerintah Daerah Kabupaten/Kota 2010-2014, BPS, Kaltim

Basuki, SH. 2007. Pengelola Keuangan Daerah, Edisi Revisi, Rajawali Pers Yogyakarta.

Gozali, Iman. 2013 Aplikasi Analisis Multivariate dengan Program IBM SPSS 21 Update PLS Regresi, Edisi 7. Badan Penerbit Universitas Diponegoro. Semarang

Halim, Abdul, 2007. Akuntansi Sektor Publik: Akuntansi Keuangan Daerah Edisi 3 Salemba Empat : Jakarta.

Hamdani, Surya, 2014, Skripsi, Pengaruh Dana Alokasi Umum dan Pendapatan Asli Daerah Terhadap Belanja Daerah Pada Kabupaten/Kota di Provinsi Kalimantan Timur. Fakultas Ekonomi, Unuversitas Mulawarman.

Haw, Widjaja. 2004. Otonomi Daerah dan Daerah Otonom. Rajawali Pers Jakarta.

Juli Panglima Saragih. (2011). Desentralisasi Fiskal dan Keuangan Daerah dalam Otonomi. Ghalia Indonesia-Jakarta

Maimunah, Mutiara 2006. Flypaper Effect pada Dana Alokasi Umum (DAU) dan Pendapatan Asli Daerah (PAD) terhadap Belanja Daerah pada Kabupaten/Kota di Pulau Sumatera, Padang.

Mardiasmo. 2008. Otonomi dan Manajemen Keuangan Daerah. Penerbit Andi : Yogyakarta 
Nordiawan, Deddi. (2007), Akuntansi Sektor Publik, Jakarta: Salemba Empat

Nugroho, Aris Adi, 2014. Analisis Pengaruh Pendapatan Asli Daerah, Dana Alokasi Umum, Dana Alokasi Khusus Terhadap Belanja Modal Pada Pemerintah Kota Balikpapan.

Pratiwi, Novi, 2007. Pengaruh Dana Alokasi Umum (DAU) dan Pendapatan Asli Daerah (PAD) terhadap Prediksi Belanja Daerah pada Kabupaten/Kota di Indonesia. Skripsi Sarjana (dipublikasikan). Fakultas Ekonomi UII: Yogyakarta

Purwanto Fiona Puspita Devi (2013), Pengaruh Pertumbuhan Ekonomi, Pendapatan Asli Daerah, Dana Alokasi Umum terhadap Belanja Modal pada Kab/kota Provinsi Jawa Tengah tahun 2008-2011

Siahaan, P. Marihot, 2005. Pajak Daerah dan Retribusi Daerah. Edisi 1, Rajagfarindo: Jakarta.

Solikin Ikin (2008), Hubungan Pendapatan Asli Daerah, Dana Alokasi Umum terhadap Belanja Modal di Provinsi Jawa Barat.

Sukriy dan Halim Abdullah (c), Pengaruh Dana Alokasi Umum (DAU) dan Pendapatrtan Asli Daerah (PAD) terhadap Belanja Pemerintah Daerah:Studi Kasus Kabupaten/Kota Di Jawa dan Bali, Simposium Nasional Akuntansi VI: 1140-1159, Surabaya 16-17 Oktober 2003.

Sumarmi, Sapta Ningsih (2011), Pengaruh Pendapatan Asli Daerah, Dana Alokasi Umum da Alokasi Khusus terhadap Belanja Modal Pada kab/kota Provinsi DI Yogyakarta

Tjandra, W. Riawan, 2006. Hukum Keuangan Negara. PT. Gasindo: Jakarta.

Trihartanto, Barata. 2006. Kekuasaan Pengelola Keuangan Negara/Daerah. Jakarta

Trihartanto, Barata. 2004. Kekuasaan Pengelola Keuangan Negara/Daerah. Berdasarkan Undangundang No.17 th.2002 Tentang Keuangan Negara. Jakarta.

Yani, Ahmad. 2002. Hubungan Keuangan Daerah antara Pemerintah Pusat dan Daerah, Edisi Revisi. Rajawali, pers Jakarta.

Zulkarnaen, Lussy Dahlia, 2013. Analisis Kontribusi Dana Alokasi Umum dan Pendapatan Asli Daerah pada Anggaran Pendapatan dan Belanja Daerah Pemerintah Kota Balikpapan. Universitas Mulawarman, Samarinda

Republik Indonesia. Undang-undang Nomor 17 Tahun 2003 Tentang Keuangan Negara.

Republik Indonesia. Undang-undang No. 32 Tahun 2004 Tentang Pemerintah Daerah.

Republik Indonesia. Undang-undang No. 33 Tahun 2004 Tentang Perimbangan Keuangan antara Pemerintah Pusat dan Pemerintah Daerah.

Republik Indonesia. Keputusan Menteri dalam Negeri Nomor 29 Tahun 2002 Tentang Pedoman, Pengurusan, Pertanggungjawaban dan Pengawasan Keuangan Daerah serta Tata Cara Penyusunan APBD, Pelaksana Tata Usaha Keuangan Daerah dan Penyusunan Perhitungan APBD.

Republik Indonesia. Undang-undang No. 28 Tahun 2009 Tentang Pajak Daerah.

Republik Indonesia. Peraturan Menteri Dalam Negeri No.26 Tahun 2006 Tentang Pedoman Penyusunan Anggaran Pendapatan dan Belanja Daerah tahun 2007.

Republik Indonesia. Peraturan Pemerintah Republik Indonesia No. 58 Tahun 2005 tentang Pengelolaan Keuangan Daerah. 